\title{
What fairness? Gendered housework division and family life satisfaction across 30 countries
}

\author{
Yang Hu \\ Department of Sociology, Lancaster University \\ Address: Bowland North, Lancaster University, Bailrigg, Lancaster, LA1 4YN, UK \\ Email: yang.hu@lancaster.ac.uk \\ Phone: +441524593429
}

Yang $\mathrm{Hu}$ is a Lecturer in the Department of Sociology at Lancaster University, UK. His research focuses on the sociology of families and intimate relationships, race/ethnicity and migration, and East Asian societies. His is the author of the book Chinese-British Intermarriage-Disentangling Gender and Ethnicity. His recent research has appeared in the Journal of Marriage and Family, Journal of Sex Research, Demographic Research, Environment and Planning A, Journal of Family Issues and British Journal of Sociology of Education.

\section{Deniz Yucel}

Department of Sociology, William Paterson University

Address: 300 Pompton Road, 465 Raubinger Hall, Wayne, NJ, 07470, USA

Email: yuceld@wpunj.edu

Phone: +1 973-720-2572

Deniz Yucel is an Associate Professor in the Department of Sociology at William Paterson University in New Jersey, United States. She obtained her MA and PhD in Sociology from 
the Ohio State University, United States. She specialises in the sociology of family, sociology of education, social stratification, work-family balance and social capital. Her current research takes a comparative approach to exploring the micro and macro determinants of relationship and family life satisfaction among married individuals and couples, as well as understanding the differential relationship dynamics between married and cohabiting couples. Her prior research has appeared in Social Science Research, Journal of Family Issues, Society and Mental Health, and Social Indicators Research.

\section{Acknowledgements}

The data used in this research are obtained from the Leibniz Institute for the Social Sciences. We are solely responsible for the analysis and interpretation of the data presented in this article. We gratefully acknowledge the helpful comments on an earlier version of this paper received at the 2017 Annual Conference of the British Sociological Association. We would like to thank the constructive and encouraging comments from the editors and anonymous reviewers. 


\title{
What fairness? Gendered division of housework and family life satisfaction across 30 countries
}

\begin{abstract}
This article sheds new light on the role played by perceived fairness in configuring the relationship between gendered housework division and women's family life satisfaction across 30 countries. This is achieved by distinguishing and comparing two major dimensions of women's fairness comparison-inter-gender relational comparison between partners and intra-gender referential comparison with other women from the same society. Analysing data from the 2012 International Social Survey Programme, we find that women's family life satisfaction is adversely affected by both a lack of relational fairness and unfavourable referential comparison, which operate independently of each other. Supporting the 'self-serving' theory, women are found to rely more on one dimension of fairness comparison to assess their family life satisfaction when they compare unfavourably rather than favourably in the other dimension. Country-level gender equality positively predicts the strength of the association between relational fairness and family life satisfaction. However, it does not seem to moderate the influence of referential comparison on family life satisfaction. In light of these results, scholars are urged to consider the perceived fairness of housework division as a plural construct, and to promulgate gender equality in multiple dimensions — addressing not just inter-gender (in)equity but also intra-gender (in)equality— to move the gender revolution forward.
\end{abstract}

\section{Key Words}

Fairness, Family Life Satisfaction, Gender, Housework, Multilevel Cross-national Analysis, Referential Comparison, Relational Comparison 


\section{Introduction}

The United Nations set the achievement of gender equality as one of its 2030 Sustainable Development Goals. However, this vision is challenged by the reality of a 'stalled' and 'uneven' gender revolution (Esping-Andersen et al., 2013). Despite considerable progress towards gender equality in the public sphere (Scott et al., 2012), progress towards domestic gender equality not only lags far behind but is uneven across the globe (Lachance-Grzela and Bouchard, 2010; Voicu et al., 2009), with some countries and regions (e.g. Northern Europe) far ahead of others (e.g. East Asia) (Esping-Andersen et al., 2013). A further dimension of imbalance in the gender revolution lies in the vast gulf between the reality of gendered housework division and how this reality is subjectively perceived. Although women undertake two thirds of the domestic work in many industrialised societies (Esping-Andersen et al., 2013; Greenstein, 2009), more than $40 \%$ of women, according to Braun et al. (2008) and Greenstein (2009), tend not to perceive the division of housework as unfair.

Subjective perceptions of the fairness of housework division matter because they speak to the ways in which women make sense of their gendered experiences and their latent tendency to (re)act upon the status quo (Braun et al., 2008; Davis and Greenstein, 2009). In this context, the widespread absence of the perception of gendered division of housework as unfair may underpin an entrenched normalisation of gender inequity (Thompson, 1991). Fairness perceptions may also form part of people's life-quality assessment (Himsel and Goldberg, 2003). A lack of perceived fairness in the division of housework might decrease women's family life satisfaction (Knudsen and Wærness, 2008), in turn increasing the odds of relationship and marital dissolution (Forste and Fox, 2012; Frisco and Williams, 2003).

Social comparison is a key mechanism of fairness evaluation (Festinger, 1954; Major, 1993; Thompson, 1991). According to the theories of distributive justice, relative deprivation and entitlement (Crosby, 1982; Himsel and Goldberg, 2003; Runciman, 1966), women may 
draw simultaneously on multiple comparison referents to construct their fairness perceptions.

Different dimensions of fairness comparison represent vastly different social and psychological processes (Buunk and VanYperen, 1991; Major, 1993; Mikula et al., 2009). However, the multiplicity of fairness comparison has received insufficient attention in existing quantitative — and particularly cross-national—research (e.g. Braun et al., 2008; Greenstein, 1996; Greenstein, 2009; Lavee and Katz, 2002), which has tended to focus on comparison between partners. ${ }^{1}$ As a result, it remains largely unclear whether and how distinct dimensions of fairness comparison may affect women's family life satisfaction in similar or different ways, and how different dimensions of comparison may interact with and/or mitigate each other. To remedy this limitation, our first objective is to explicitly theorise, measure and compare distinct dimensions of fairness comparison — namely inter-gender comparison between partners and intra-gender comparison within a given society-and characterise their respective and interactive roles in configuring women's family life satisfaction.

The perceived fairness of housework division and its implications for family life satisfaction are further moderated by justification processes, i.e. the legitimisation of the appropriateness of the gendered division of housework (Major, 1993; Thompson, 1991). To date, researchers have focused on individual-level dynamics; the socially embedded and context-dependent nature of perceived fairness has received less attention (Ferree et al., 1999). The few exceptions to take a cross-national approach have yielded valuable insights into the salience of national context in configuring perceived fairness and its impact on family life satisfaction (e.g. Braun et al., 2008; Forste and Fox, 2012; Greenstein, 2009; Knudsen and Wærness, 2008; Ruppanner, 2010). However, it is unclear from these studies whether and how national context may moderate distinct dimensions of individual-level fairness comparison in similar or different ways. It is important to distinguish between 
dimensions of contextual moderation because they represent distinct modes of individual-context interaction and different ways of understanding the 'unevenness' of the gender revolution across countries (Walby, 2009). Our second objective is thus to disentangle and compare the ways in which national context may condition different dimensions of fairness comparison, moderating their influences on women's satisfaction with family life.

\section{Theoretical Considerations and Hypotheses}

\section{Housework Division, Perceived Fairness and Satisfaction with Family Life}

Bridging the gap between the objective division of domestic labour and subjective perceptions of that division, the distributive justice framework provides valuable insights into why, when and how gendered housework division matters to women's family life satisfaction (Major, 1993; Thompson, 1991). Within this framework, it is axiomatic that a justice phenomenon - the construction of fairness perception — must be activated for a link to be established between housework division and subjective life-quality assessment (Thompson, 1991). The framework has received extensive empirical support (e.g. Braun et al., 2008; Greenstein, 1996; Lavee and Katz, 2002; Lennon and Rosenfield, 1994).

Three components are operative in the activation of justice phenomena: outcome, comparison and justification. First, individuals must value the outcome of an equitable division of housework to initiate the process of fairness evaluation. Second, social comparison plays a vital role in fairness evaluation, as highlighted by scholars such as Crosby (1982), Festinger (1954), Himsel and Goldberg (2003) and Runciman (1966). This is consistent with the symbolic interactionist perspective in that individuals refer to other social actors and contextual norms to validate the meaning of 'doing' housework (West and Zimmerman, 1987). Third, justifications of or beliefs about the appropriateness of the procedures responsible for the distribution of housework are crucial to determining perceived 
fairness and its consequences (Major, 1993). As an outcome of fairness comparison, the performance of domestic chores is generally considered 'undesirable' (Scott et al., 2012), and people tend to seek equity in relationships (Greenstein, 2009). In this research, therefore, we expand on the latter two components to provide a nuanced examination of fairness comparison, justification and the interaction between the two in a cross-national context.

\section{Dimensions of Fairness Comparison}

Fairness comparison has been well established as a multifaceted and multi-scalar process (Festinger, 1954; Major, 1993; Runciman, 1966). Partly due to data limitations, however, quantitative empirical research on the gendered division of housework has tended to restrict fairness comparison to a single dimension: between partners (e.g. Braun et al., 2008; Greenstein, 1996; Greenstein, 2009; Lavee and Katz, 2002). The multifaceted nature of fairness comparison has been explicitly addressed in only a few qualitative and small-scale studies (e.g. Freudenthaler and Mikula, 1998; Himsel and Goldberg, 2003; Kluwer, 1998; Mikula et al., 2009). However, these studies clearly illustrate the importance of considering fairness comparison as a plural construct.

Although numerous referents are possible, two main referents appear to be used by women to construct fairness perceptions. First, women may conduct inter-gender comparison with their partners (Braun et al., 2008; Greenstein, 1996; Major, 1993; Ruppanner, 2010; Thompson, 1991), with whom they have direct social exchange relationships. According to Buunk and VanYperen (1991) and Crosby (1982), the goal of such 'relational comparison' is to eliminate relative deprivation and attain a sense of equity. Given that in many countries, women spend twice as much time on housework as men despite their high rate of labour force participation (Lachance-Grzela and Bouchard, 2010; Voicu et al., 2009), inter-gender relational comparison is likely to lead to a lack of perceived fairness (Frisco and Williams, 
2003; Greenstein, 1996; Himsel and Goldberg, 2003), which may adversely affect women's family life satisfaction.

Second, women may look beyond the home, carrying out intra-gender comparison with other women from the same society (Freudenthaler and Mikula, 1998; Himsel and Goldberg, 2003; Kluwer, 1998). This process of comparison does not necessarily involve concrete social interaction or exchange, and is conducted for validation and referential purposes. According to Buunk and VanYperen (1991), the goal of such 'referential comparison' is to gain comparative advantages (rather than to attain equity) by constructing the favourable sense that one is faring better (i.e. undertaking a smaller share of the housework) than other women. Referential comparison may be further calibrated by certain comparative frames, as women are typically seen to choose those with comparable traits (e.g. similar gender ideologies) as referents (Davis and Greenstein, 2009; Runciman, 1966; Himsel and Goldberg, 2003). Previous research has shown that a margin of advantage perceived through referential comparison may positively predict women's satisfaction with family life, while a perceived relative disadvantage may negatively affect their family life satisfaction (Himsel and Goldberg, 2003; Mikula et al., 2009). If the above two dimensions of fairness comparison indeed differ in their underlying constructs, mechanisms and scope, we would expect them both to have a net influence on women's family life satisfaction, independent of each other (i.e. without mediating each other's effect).

\section{Hypothesis 1 (inter-gender relational fairness comparison between partners):} women's perceptions of the fairness of the division of housework between partners is positively associated with their family life satisfaction. 
Hypothesis 2 (intra-gender referential comparison within country): women's favourable comparison with other women from the same country in terms of the division of housework is positively associated with their family life satisfaction.

In reality, the two dimensions of fairness comparison are likely to operate in conjunction rather than separately in isolation. Women not only refer simultaneously to different referents (Thompson, 1991; Freudenthaler and Mikula, 1998; Kluwer, 1998), but are also seen to consciously choose between and rely on different referents to conduct fairness comparison (Buunk and VanYperen, 1991). Based on the principle of dissonance reduction (Festinger 1954, 1962), the choice of referents tends to be 'self-serving' and 'harm-evasive' (Buunk and VanYperen, 1991). When multiple referents are available, women are likely to veer away from the less favourable and opt for the more favourable referent to establish and reinforce a positive view of their situation (Major, 1993). If the 'self-serving' conjecture holds true in women's choice of relational vs referential comparison, we would expect one dimension of comparison to matter more when women compare unfavourably rather than favourably in the other dimension.

Hypothesis 3 (moderating effect between the two dimensions of fairness comparison): the association between family life satisfaction and referential comparison is stronger when women compare unfavourably rather than favourably with their partners in terms of the division of housework.

\section{Fairness Justification and National Context}

Fairness justification entails the legitimisation of certain outcomes of fairness comparison as reasonably expected, normalised and thus irrelevant to life-quality assessment (Braun et al., 
2008; Major, 1993). The moderating effect of justification on the relationship between fairness comparison and family life satisfaction at the individual level has received extensive empirical support in terms of gender ideology (Davis and Greenstein, 2009; Greenstein, 1996; Lavee and Katz, 2002), marital power and relative resources (Lennon and Rosenfield, 1994) and role strain and time constraints (Braun et al., 2008; Ruppanner, 2010). Although the notion that both social justice and gender dynamics are socially embedded and operate at multiple cross-cutting levels of society is no longer new (Ferree et al., 1999), only a handful of researchers have adopted a multilevel approach and explicitly focused on country-level justification (Braun et al., 2008; Forste and Fox, 2012; Greenstein, 2009; Ruppanner, 2010). These studies specifically addressed relational comparison between partners and showed that both the dynamics and the consequences of comparison vary considerably by country. Although we know little about whether and how national context may condition referential comparison, there is good reason to expect that relational comparison and referential comparison relate to national context in different ways, as they are based on considerably different constructs.

National context may moderate the perceived fairness of housework division via two major mechanisms. First, the level of gender (in)equality is indicative of prevalent gender norms in a given country (Davis and Greenstein, 2009), and individuals draw on such norms to enact and regulate their gender performance (West and Zimmerman, 1987). The association between femininity and housework performance is normalised to a greater degree in countries with a lower than a higher level of gender equality (Ferree et al., 1999; West and Zimmerman, 1987). This normalisation may act as a 'buffer' that prevents women from invoking justice phenomena over gendered housework division (Greenstein, 2009). Second, country-level gender equality confers a level of gender empowerment (e.g. institutional, legal and policy provisions for gender equality) that may encourage women to view the division of 
housework as a distributive justice process and to seek a sense of fairness in this process (Braun et al., 2008). Women may thus be more empowered to exercise their agency and invoke justice phenomena over gendered housework division in countries with a higher than a lower level of gender equality (Greenstein, 2009; Scott et al., 2012; Walby, 2009).

It is worth noting that both of the above mechanisms are primarily concerned with the relative gender roles and equity between women and men (Crosby, 1982; Greenstein, 2009). Therefore, we would expect country-level gender equality to affect women's perceptions of fairness based on relational comparison between partners (Greenstein, 2009), as specified in Hypothesis 4. In contrast, however, neither of the above mechanisms explicitly encourage women to conduct referential comparison with other women; nor do they underline the importance of intra-gender equality between women. Therefore, if the activation of fairness perceptions requires an exact match between fairness justification at the country level and specific dimensions of fairness comparison, we would not expect contextual forces with an emphasis on female-male equality to moderate the influence of intra-gender referential comparison on family life satisfaction. However, if the activation of fairness perception is dependent on more diffuse contextual forces, women may be more sensitive to the issue of housework division in general, and thus more susceptible to referential comparison with other women, in countries with a higher level of gender equality. This supposition is specified in Hypothesis 5.

Hypothesis 4 (contextual moderation of relational fairness): the association between between-partner relational comparison and women's family life satisfaction is stronger in countries with a higher level of gender equality. 
Hypothesis 5 (contextual moderation of referential comparison): the association between within-country referential comparison and women's family life satisfaction is stronger in countries with a higher level of gender equality.

\section{Data and Sample}

We drew on two sources of data. The individual-level data were obtained from the 2012 release of the International Social Survey Programme (ISSP), entitled 'Family and Changing Gender Roles' (IV). The ISSP is an annual survey programme that collects cross-sectional cross-national data covering a diverse array of important topics of social science research. Although sampling procedures differ slightly between countries, the ISSP is generally based on a simple or multi-stage stratified random sample of households, with one respondent aged 16 or above selected randomly from each household. The resulting sample is representative of the adult population in a given participating country. The 2012 ISSP provides the most up-to-date and comparable measures of people's gender ideologies, housework division and family life satisfaction across a wide range of countries. The country-level indicators were obtained from the United Nations Development Programme (UNDP, 2012).

To construct our analytical sample, we used data from 30 countries: Argentina, Australia, Austria, Bulgaria, Canada, Chile, Croatia, Czech, Denmark, Finland, France, Germany, Iceland, Ireland, Israel, Japan, Korea (South), Latvia, Lithuania, Mexico, Norway, the Philippines, Poland, Russia, Slovakia, Slovenia, Sweden, Switzerland, the United Kingdom and the United States. Seven countries originally covered by the 2012 ISSP, namely China, India, Spain, South Africa, Taiwan, Turkey and Venezuela, were excluded from the analytical sample due to the absence of comparable or reliable measures for the key variables.

We restricted our sample to women, because the gender ideology measures focused on women's (rather than men's) gender role, and men have been known to provide inaccurate 
estimates of their housework time (Lee and Waite, 2005). As the focus of the research was the relative division of housework between women and men, and as the dynamics of same-sex union vary considerably across countries, we further restricted our analytical sample to respondents in unmarried or married heterosexual cohabiting relationships. Of the 12,785 women who co-resided with their partners in the 30 countries sampled, 2,318 (c. $18 \%$ of the original ISSP sample) were eliminated for failing to provide valid information on key variables such as family life satisfaction, gender ideology and housework division, yielding an analytical sample of 10,467 women. Further tests indicated that the respondents eliminated due to missing information on the key variables were older $\left(M_{\text {age }}=50.57, S D=16.02\right)$ than those who provided full sets of information $\left(M_{\mathrm{age}}=47.30, S D=14.30 ; t=9.90, p<.001\right)$. As a result, our analytical sample slightly under-represented elder females. Table 1 presents summary statistics for all of the variables for the analytical sample (see Supplementary Table S1 for descriptive statistics aggregated at the country level).

[Table 1 about here]

\section{Key Variables}

\section{Satisfaction with Family Life}

In the 2012 ISSP, the respondents were asked the following question: 'all things considered, how satisfied are you with your family life?' The responses were recorded on a 7-point scale ranging from 'completely satisfied' (1) to 'completely dissatisfied' (7). We reversed the scale so that a higher score indicated greater family life satisfaction. The indices fell within a range sufficient to assume a normal distribution.

\section{Women's Share of Couples' Housework Time}


The survey respondents were asked to report the number of hours per week they and their co-residing partners, respectively, spent on housework (not including care provision).

Although this generic measure provides a less accurate estimate of time than time diaries, the ISSP is the only large-scale cross-national survey to contain measures of gender ideology, housework division and family life satisfaction. According to Lee and Waite (2005), women tend to accurately estimate both their own and their partners' housework time. To minimise the influence of outlier responses, we replaced the top $1 \%$ of the reports of the respondents' and spouses' weekly housework time to be equal to the $99^{\text {th }}$ percentile rank of 69 hours per week. The women spent an average of 19.88 hours on housework per week. We divided each woman's weekly housework time by the corresponding couple's total weekly housework time to yield the respondent's relative share of the couple's housework time. The measure ranged between 0 and 1 , with 0 indicating that the woman undertook none of the housework and 1 indicating that the woman undertook all of the housework. On average, the women shouldered $71 \%$ of the total housework time. Our additional checks indicated that this time-use measure was consistent with the measures used in previous research (see Supplementary Table S2).

\section{Gender Ideology}

The respondents were asked to report on a 5-point scale the degree to which they agreed with each of the following statements: (a) 'a working mother can establish just as warm and secure a relationship with her children as a mother who does not work', (b) 'all in all, family life suffers when the woman has a full-time job', (c) 'a job is alright, but what most women really want is a home and children', (d) 'being a housewife is just as fulfilling as working for pay' and (e) 'a man's job is to earn money; a woman's job is to look after the home and family'. The same indicators have been used in a number of existing studies to measure gender 
ideology (Braun et al., 2008; Greenstein, 2009). For each indicator, a higher score consistently indicated stronger disagreement with the statement and thus a less traditional gender ideology. Exploratory factor analysis, specifically Varimax rotation, showed that the five measures formed a single factor with an eigenvalue of 1.46. Next, the Bartlett method was used to extract the gender-ideology index, with a higher score indicating a more egalitarian ideology. The value of Cronbach's alpha indicated a high level of internal consistency among the five indicators $(\alpha=0.78)$, and the alpha score could not be increased further by adding or eliminating items.

\section{Dimensions of Fairness Comparison}

Inter-gender relational comparison between partners. The respondents were asked the following question: "which of the following best applies to the sharing of household work between you and your spouse/partner?' The responses were coded on a 5-point scale ranging from 'I do much more than my fair share' $(1,29.6 \%)$ through 'I do more than my fair share' (2, 26.8\%), 'I do about my fair share' $(3,38.6 \%)$ and 'I do less than my fair share' $(4,3.3 \%)$ to 'I do much less than my fair share' $(5,1.7 \%)$. In previous research, this variable has been coded as a categorical measure (Braun et al., 2008; Lavee and Katz, 2002) or a continuous measure (Greenstein, 2009). As the indices fell within a range sufficient to assume a normal distribution, we coded the variable as a continuous measure, with higher values indicating greater perceived fairness. The women who reported undertaking less than their fair share of housework may also have experienced less family life satisfaction due to the lack of equity in housework division. However, the results of our additional tests based on a sample excluding these women and using an ordinal coding scheme were consistent with those reported here (see Supplementary Table S3 Panel A and S4 Panel A). 
Intra-gender referential comparison within country. To measure within-country referential comparison (Major, 1993; Thompson, 1991), we first calculated the country-specific percentile rankings of the gender-ideology index and women's share of couples' housework time, respectively. We reversed the latter ranking so that a higher score indicated a smaller share of female housework time and thus a less traditional housework division. We then calculated the referential comparison index by subtracting the gender ideology percentile rank score from the housework share percentile rank score. The index, originally ranging from -99 to 99 , was rescaled to range from -0.99 to 0.99 to enhance the efficiency of multilevel modelling (Snijders and Bosker, 2011). A value of 0 indicated a 'level comparison', i.e. the respondent ranked similarly in terms of both housework division and gender ideology relative to other women in a given country. A smaller (more negative) value indicated an 'unfavourable comparison', i.e. the respondent ranked farther towards the inequitable side of housework division than that of gender ideology. Conversely, a larger (more positive) value indicated a 'favourable comparison', i.e. the respondent ranked farther towards the less traditional side of housework division than that of gender ideology. When gender ideology is controlled for in statistical models, the index would denote the degree to which the respondents undertook a more (or less) egalitarian share of housework compared with other women in the same country displaying similar gender ideologies.

\section{Country-level Gender Equality}

To measure the overall level of gender equality in each country, we drew on the 2012 gender inequality index developed by the UNDP. Constructed from multiple indicators of progress towards gender equality, such as education, political empowerment, labour-market participation and economic empowerment, the index provides a synthesised measure of the overall level of gender (in)equality in each country. The original index ranged between 0 and 
1 ; we reversed the index so that a larger value indicated a higher level of gender equality in a given country. We then standardised the index to take a mean value of 0 and a standard deviation of 1 .

\section{Covariates}

We controlled for the respondents' age and its quadratic form to account for potential non-linearity. The respondents were between 17 and 79 years old. We distinguished between unmarried (14\%) and married cohabiting relationships. We also controlled for respondents' years of schooling as a linear regressor $(M=12.89, S D=3.82)$. Religiosity is known to enforce traditional gender roles and ideologies (Voicu et al., 2009). Thus, we controlled for respondents' self-reported religious affiliation using a series of dummy variables, noting whether the respondents were Catholic (38\%), Protestant (22\%) or affiliated with any other Christian (10\%) or non-Christian (8\%) religions. As individuals' health may influence their family life satisfaction and the degree to which they are capable of performing housework, we also took account of the respondents' self-reported health, which was recorded on a 5-point scale ranging from 'excellent' (1) to 'poor' (5). We reversed the scale so that a higher score indicated a better state of self-perceived health.

We took account of women's time availability by controlling for their weekly paid work hours $(M=22.36, S D=20.61)$. To minimise the influence of outlier responses, we replaced the top $1 \%$ of reported weekly paid work time to be equal to the $99^{\text {th }}$ percentile rank of 80 hours per week. Women's perceptions of the fairness of housework division may be mitigated by their economic (in)dependence (Lennon and Rosenfield, 1994). In the ISSP, the respondents were asked the following question: 'considering all sources of income, between you and your spouse/partner, who has the higher income?'. The answers were recorded on a 7-point scale ranging from 'my spouse/partner has no income' (1) through 'we have about the 
same income' (4) to 'I have no income' (7). A larger value indicated a higher level of resource dependence. As both housework division and fairness perception are susceptible to the use of domestic outsourcing (Lennon and Rosenfield, 1994), we coded a case as 'using domestic aid' if one or more routine chores (e.g. laundry, cleaning, preparing meals or shopping) were done by a third person (11\%). Family socioeconomic status was controlled for using the quartile rank of household income in 2012 for each country. As around $20 \%$ of the respondents in our analytical sample failed to provide income information, we coded the missing responses as a separate category in addition to the quartile rank to minimise sample loss. Country-level economic development is known to condition both the demand for domestic labour at the household level and the perception of the fairness of housework division (Greenstein, 2009). Thus, we controlled for the national gross domestic product per capita in 2012.

In our preliminary analysis, we experimented with including a number of additional variables: whether respondents resided in rural or urban areas, the duration of marriage, the presence of pre-school (aged between 0 and 6) minor children, the presence of school-aged minor children (aged between 7 and 17) and the number of routine residents in the household. These variables were excluded from the analysis reported in this article because they were not found to be significantly associated with family life satisfaction, and their inclusion neither affected the interpretation of the other variables nor helped to increase the overall model fit.

\section{Analytical Strategy}

The analysis was performed using two-level mixed-effects models (Bryan and Jenkins, 2016). Model 1 included all of the variables except the two fairness comparison measures. Model 2 and Model 3 further included relational comparison with partner and referential comparison 
within country, respectively. To examine the potential mediating effects of different dimensions of fairness comparison, we included both fairness comparison measures in Model 4. In Model 5, we tested the 'self-serving' hypothesis by including the interaction between relational comparison and referential comparison. Model 6 to Model 9 were fitted to test the contextual moderation hypotheses. In Model 6 and Model 8, we included random slopes for relational comparison and referential comparison, respectively, for each country. In Model 7 and Model 9, we added the interaction terms of country-level gender equality with relational comparison and referential comparison, respectively. We then compared Models 6 and 7 and Models 8 and 9 to estimate the degree to which the random slope for each dimension of fairness comparison was explained by the varying levels of gender equality across the 30 countries (Schmidt-Catran and Fairbrother, 2016)

A number of additional tests were conducted to ensure the robustness of the results. First, the results reported in this article were robust when the analytical sample was limited to women aged between 30 and 60 (see Supplementary Table S3 Panel B and Table S4 Panel B). Second, the results were also robust to the non-linear specifications of birth cohort and women's weekly paid work time (see Supplementary Table S3 Panel C and Table S4 Panel C). Third, although our main aim was to examine cross-level interactions, the results were robust to the inclusion of a number of individual-level interactions (see Supplementary Table S5). Fourth, variance inflation factor (VIF) tests yielded VIF values well below the threshold of 5 for all variables except the quadratic term of age.

\section{Results}

\section{Family Life Satisfaction: Relational and Referential Fairness Comparison}

Table 2 presents the results (unstandardised coefficients) of the two-level mixed-effects models predicting women's family life satisfaction. Notably, we also present standardised 
coefficients (denoted by the Greek letter ' $\beta$ ') and predictive margins with $95 \%$ confidence intervals in the text to aid the interpretation and comparison of effect sizes. To conserve space, we present the results for the covariates from the full model (i.e. Model 4 in Table 2) in Supplementary Table S6, as these results were highly consistent across the models.

[Table 2 about here]

The results from Model 2 supported Hypothesis 1: that women's perceptions of the fairness of the division of housework between partners positively predicts their satisfaction with family life. The women enjoyed greater family life satisfaction when they perceived the division of housework between partners to be fair (relational fairness $=5$, predictive margin: $5.911[5.849,5.972])$ rather than unfair (relational fairness $=1$, predictive margin: 5.530 $[5.498,5.561])$, when all other continuous variables took the mean level and categorical variables took the mode of the sample. The association between relational fairness and family life satisfaction was also sizeable ${ }^{2}(\beta=0.091[0.071,0.111])$ compared with the equivalent associations of variables such as gender ideology $(\beta=-0.078[-0.098,-0.059])$, resource dependence $(\beta=0.025[0.005,0.045])$ and country-level economic development $(\beta=0.093[-$ $0.004,0.191])$, which are traditionally understood to have a considerable impact on women's family life satisfaction (Greenstein, 2009; Greenstein, 1996; Lennon and Rosenfield, 1994). Notably, the inclusion of relational comparison between partners in Model 2 mediated $31.11 \%$ of the association between women's actual share of housework and their family life satisfaction.

The results from Model 3 supported Hypothesis 2: that women's family life satisfaction is positively associated with their favourable intra-gender referential comparison within country. The women enjoyed greater family life satisfaction when their share of housework compared favourably (referential comparison $=1.5$ standard deviations above the mean, predictive margin: $5.843[5.733,5.954])$ rather than unfavourably (referential comparison $=$ 
1.5 standard deviations below the mean, predictive margin: $5.449[5.339,5.558])$ with that of other women from the same country with a similar gender ideology, holding constant all other continuous variables at the mean level and categorical variables at the mode of the sample. The inclusion of referential comparison mediated $81.76 \%$ of the association between women's share of housework and their family life satisfaction. The effect size of referential comparison (Model 4: $\beta=0.112[0.042,0.182]$ ) was also comparable to that of relational comparison between partners (Model 4: $\beta=0.093$ [0.072, 0.114]). Notably, in Model 4, the inclusion of both dimensions of fairness comparison mediated and thus explained almost all of the association between women's family life satisfaction and their share of housework.

Comparing Models 2, 3 and 4 clearly reveals that the two dimensions of fairness comparison had little mediation effect. Relational fairness mediated $14.04 \%$ of the association between referential comparison and family life satisfaction, whereas referential comparison mediated as little as $1.86 \%$ of the association between relational fairness and family life satisfaction. This is consistent with the theoretical premise that the two dimensions have distinct underlying constructs and mechanisms, and may thus affect women's family life satisfaction through independent channels.

[Figure 1 about here]

The results of Model 5 supported Hypothesis 3: that the association between referential fairness comparison and family life satisfaction is stronger when the perceived level of relational fairness between partners is low rather than high. To aid interpretation of the interaction effect, Figure 1 depicts the predictive margin of family life satisfaction by women's referential comparison within country at distinct levels of perceived fairness between partners. It is clear that relational fairness made a much bigger difference to women's family life satisfaction when they compared unfavourably (left end of Figure 1) rather than favourably (right end of Figure 1) with other women from the same country. 
Therefore, the results supported the theory of 'self-serving dissonance reduction' (Buunk and VanYperen, 1991; Festinger, 1954; Major, 1993), which suggests that women rely on more favourable comparison referents in their life-quality assessment to maximise their satisfaction with family life.

\section{Cross-country Moderation: Relational vs Referential Fairness Comparison}

Table 3 presents the results (unstandardised coefficients) for the cross-level interactions between country-level gender equality and the two dimensions of individual-level fairness comparison, respectively. We also present the standardised coefficients in the text to aid the interpretation and comparison of effect sizes. In Figure 2, we illustrate these interactions by plotting the predictive margins of family life satisfaction by relational (Panel A) and referential (Panel B) fairness comparison, respectively, at distinct levels of country-level gender equality.

[Table 3 and Figure 2 about here]

The results supported Hypothesis 4 (Model 7), as country-level gender equality moderated the strength of the association between women's family life satisfaction and relational fairness between partners. As depicted in Panel A of Figure 2, the slopes for relational fairness were substantially steeper in countries with a higher level of gender equality. When the division of housework between partners was perceived to be unfair (left end of Panel A), women enjoyed substantially less family life satisfaction in countries with greater gender equality. In contrast, when women perceived the division of housework between partners to be fair (right end of Panel A), their family life satisfaction varied little with country-level gender equality. The strength of this cross-level interaction was considerable $(\beta=0.019[0.002,0.037])$ when compared with the individual-level interactions of relational fairness with gender ideology $(\beta=-0.011[-0.029,0.007])$, paid work time $(\beta=$ 
$-0.015[-0.033,-0.004])$ and resource dependence $(\beta=-0.012[-0.030,0.006])$, respectively (see Supplementary Table S6). Yet the latter factors have been identified as the major justifications that may moderate women's perceptions of the fairness of the division of housework between partners (Braun et al., 2008; Greenstein, 1996; Lennon and Rosenfield, 1994).

The importance of national context in conditioning the link between relational fairness and women's family life satisfaction is also supported by the model fit indices. In Model 6, the addition of random slopes for relational fairness substantially improved the overall model fit relative to the full model (i.e. Model 4, $\Delta \mathrm{BIC}_{\mathrm{M} 6-\mathrm{M} 4}=-11.71, \Delta \mathrm{LL}_{\mathrm{M} 6-\mathrm{M} 4}=$ 10.48). In particular, the inclusion of the interaction between relational fairness and country-level gender equality in Model 7 explained 24.12\% of the random-slope variance for relational fairness across the 30 countries. The results concur with the assumption of the distributive justice framework that country-level gender equality may help denormalise and invoke justice phenomena over the gendered division of housework (Braun et al., 2008; Greenstein, 2009).

Hypothesis 5 was not supported by the results (Model 9), as the strength of the association between women's referential comparison within country and their family life satisfaction was not found to vary with country-level gender equality. Although the random slopes for referential comparison were statistically significant at the $10 \%$ level (Model 8), the inclusion of cross-level interaction between referential comparison and country-level gender equality (Model 9) reduced the random-slope variance by $0.48 \%$ only. This is vividly depicted in Panel B of Figure 2, in which all of the slopes are parallel and the confidence intervals considerably overlap. Taken together, the results indicate that country-level gender equality between women and men configures only inter-gender relational comparison 
between male and female partners; it does not seem to diffusely affect women's intra-gender referential comparison.

\section{Conclusions and Discussion}

The 'stalled' and 'uneven' gender revolution in the domestic sphere may have important implications for women's satisfaction with family life (Forste and Fox, 2012; Frisco and Williams, 2003; Lavee and Katz, 2002); and this revolution is unlikely to move forward without the realisation that the gendered division of household work is unfair and inequitable (Braun et al., 2008; Freudenthaler and Mikula, 1998; Kluwer, 1998). Expanding on the distributive justice framework of housework division (Major, 1993; Thompson, 1991), we contribute to existing scholarship by (1) explicitly theorising, measuring and comparing distinctive dimensions of fairness comparison and their interactive roles in determining women's family life satisfaction, and (2) disentangling the ways in which country-level gender equality conditions the implications of different dimensions of fairness comparison for family life satisfaction. Our analysis of cross-national data from the 2012 ISSP and the UNDP yielded the following three major findings, which provide fresh and crucial insights into the progress of the domestic gender revolution.

First, we argued for and demonstrated the importance of considering the perceived fairness of housework division as a plural rather than a unidimensional construct. Previous research has focused on fairness comparison between partners (e.g. Braun et al., 2008; Greenstein, 1996 and 2009; Lavee and Katz, 2002; Lennon and Rosenfield, 1994; Ruppanner, 2010). However, our results clearly showed that both a lack of inter-gender relational fairness between partners and relatively unfavourable intra-gender referential comparison within a given society had a considerable net negative association with women's satisfaction with family life. The two dimensions of fairness comparison had little mediation effect, but 
together they mediated and thus explained the link between gendered housework division and family life satisfaction. These results underline the fact that women may draw simultaneously on multiple referents to evaluate fairness. As substantially different mechanisms underlie the two dimensions of fairness comparison (i.e. equitable social exchange and relative deprivation for relational fairness vs social advantage for referential comparison; see Buunk and VanYperen, 1991; Major, 1993; Thompson, 1991), it is essential to distinguish the different dimensions in both conceptualisation and operationalisation.

Second, distinct dimensions of fairness comparison do not operate in isolation to determine women's family life satisfaction. We found a notable moderation effect between the two dimensions of fairness comparison. The association between one dimension of fairness comparison and family life satisfaction was stronger when women compared unfavourably or otherwise perceived a lack of fairness in the other dimension. This is consistent with the 'self-serving' theory: individuals tend to rely on the least unfavourable referent to construct their fairness perceptions as a 'dissonance reduction' strategy to maximise their subjectively perceived life satisfaction (Crosby, 1982; Festinger, 1954 and 1962). As a result, as long as women continue to fall back on the more 'favourable' comparison referent to evade 'harm' and reinforce a positive view of the status quo, the progress of the domestic gender revolution is likely to falter at the weakest chain that provides the most 'convenient' justification for the gendered division of domestic labour. Therefore, the finding reiterates the importance of distinguishing between dimensions of fairness comparison and examining their interaction to address intersecting challenges to the domestic gender revolution (Esping-Andersen et al., 2013; Walby, 2009).

Third, the findings shed new light on the role of individual-context interaction in justifying the outcomes of fairness comparison with regard to the division of housework, reflecting critically on mainstream gender equality and feminist agendas (Scott et al., 2012). 
It is hardly a novel observation that individual-level gender dynamics are socially embedded and context dependent (Ferree et al., 1999; Greenstein, 2009; West and Zimmerman, 1987). However, it remains largely unclear whether macro-level gender equality provides a diffuse sense of gender empowerment/normalisation or whether this empowerment/normalisation is limited to specific dimensions of fairness perception. Our results supported the latter assumption, as country-level gender equality was found to moderate the impact on women's family life satisfaction of inter-gender relational fairness between partners alone - not that of intra-gender referential comparison within a given country. This finding is unsurprising, because gender and feminist campaigns predominantly emphasise equality between women and men (Scott et al., 2012), not equality among women. When considered in conjunction with women's 'self-serving' strategy of constructing perceptions of fairness, the results suggest that it is insufficient to focus on only one dimension of fairness comparison, such as the equality between women and men. To move the domestic gender revolution forward, it is also crucial to consider (in)equality amongst women, to reduce intra-gender disparities, and to invoke justice phenomena over the gendered division of housework in multiple dimensions.

The limitations of this study suggest several important directions for future research. First, we focused on two distinct dimensions of fairness comparison to illustrate the theoretical salience of comparing dimensions of fairness perception; it will be important for future scholars to consider a broader range of comparison referents, such as intergenerational and temporal comparisons. Second, as the ISSP surveyed only one randomly selected member of each couple, future researchers could collect data from both partners to investigate the intersection between dyadic dynamics at couple level and in distinct national contexts. Third, as we analysed cross-sectional data, the results can only be interpreted in terms of association, not causality. Unpacking the long-term dynamics and consequences of 
the perceived fairness of housework division - i.e. whether and how individuals (re)act on perceiving a lack of fairness - is an important task for future research. Fourth, our focus on women tells only half of the story. It is also crucial to collect and analyse reliable data from men to provide comprehensive recommendations for advancing the gender revolution.

\section{Notes}

1. We use the term 'partner' to refer to both married spouses and the members of unmarried cohabiting couples.

2. As different predictors were coded on different scales, we standardised all continuous predictors in our additional tests to compare the effect sizes of different variables, in addition to the unstandardised coefficients presented in the tables. The dependent variable was not standardised. 


\section{References}

Braun, M., Lewin-Epstein, N., Stier, H., and Baumgärtner, M. K. (2008). Perceived equity in the gendered division of household labor. Journal of Marriage and Family, 70, 11451156.

Bryan, M. L., and Jenkins, S. P. (2016). Multilevel modelling of country effects: A cautionary tale. European Sociological Review, 32, 3-22.

Buunk, B. P., and VanYperen, N. W. (1991). Referential comparisons, relational comparisons, and exchange orientation: Their relation to marital satisfaction', Personality and Social Psychology Bulletin, 17, 709-717.

Crosby, F. J. (1982). Relative Deprivation and Working Women. New York: Oxford University Press.

Davis, S. N., and Greenstein, T. N. (2009). Gender ideology: Components, predictors, and consequences. Annual Review of Sociology, 35, 87-105.

Esping-Andersen, G., Boertien, D., Bonke, J., and Gracia, P. (2013). Couple specialization in multiple equilibria. European Sociological Review, 29, 1280-1294.

Ferree, M. M., Lorber, J., and Hess, B. B. (1999). Revisioning Gender. Oxford: Rowman Altamira.

Festinger, L. (1954). A theory of social comparison processes. Human Relations, 7, 117-140.

Festinger, L. (1962). A Theory of Cognitive Dissonance. Redwood City, CA: Stanford University Press.

Forste, R., and Fox, K. (2012). Household labor, gender roles, and family satisfaction: A cross-national comparison. Journal of Comparative Family Studies, 43, 613-631.

Freudenthaler, H. H., and Mikula, G. (1998). From unfulfilled wants to the experience of injustice: Women's sense of injustice regarding the lopsided division of household labor. Social Justice Research, 11, 289-312. 
Frisco, M. L., and Williams, K. (2003). Perceived housework equity, marital happiness, and divorce in dual-earner households. Journal of Family Issues, 24, 51-73.

Greenstein, T. N. (1996). Gender ideology and perceptions of the fairness of the division of household labor: Effects on marital quality. Social Forces, 74, 1029-1042.

Greenstein, T. N. (2009). National context, family satisfaction, and fairness in the division of household labor. Journal of Marriage and the Family, 71, 1039-1051.

Himsel, A. J., and Goldberg, W. A. (2003). Social comparisons and satisfaction with the division of housework. Journal of Family Issues, 24, 843-866.

Kluwer, E. S. (1998). Responses to gender inequality in the division of family work: The status quo effect. Social Justice Research, 11, 337-357.

Knudsen, K., and Wærness, K. (2008). National context and spouses' housework in 34 countries. European Sociological Review, 24, 97-113.

Lachance-Grzela, M., and Bouchard, G. (2010). Why do women do the lion's share of housework? A decade of research. Sex Roles, 63, 767-780.

Lavee, Y., and Katz, R. (2002). Division of labor, perceived fairness, and marital quality: The effect of gender ideology. Journal of Marriage and Family, 64, 27-39.

Lee, Y. S., and Waite, L. J. (2005). Husbands' and wives' time spent on housework: A comparison of measures. Journal of Marriage and Family, 67, 328-336.

Lennon, M. C., and Rosenfield, S. (1994). Relative fairness and the division of housework: The importance of options. American Journal of Sociology, 100, 506-531.

Major, B. (1993). Gender, entitlement, and the distribution of family labor. Journal of Social Issues, 49, 141-159.

Mikula, G., Schoebi, D., Jagoditsch, S., and MacHer, S. (2009). Roots and correlates of perceived injustice in the division of family work. Personal Relationships, 16, $553-$ 573. 
Runciman, W. G. (1966) Relative Deprivation and Social Justice. Berkeley: University of California Press.

Ruppanner, L. (2010). Conflict and housework: Does country context matter? European Sociological Review, 26, 557-570.

Schmidt-Catran, A. W., \& Fairbrother, M. (2016). The random effects in multilevel models: Getting them wrong and getting them right. European Sociological Review, 32, 2338.

Scott, J. L., Dex, S., and Plagnol, A. (2012). Gendered Lives: Gender Inequalities in Production and Reproduction. Cheltenham: Edward Elgar Publishing.

Snijders, T. A. B., and Bosker, R. J. (2011). Multilevel Analysis: An Introduction to Basic and Advanced Multilevel Modeling. London: Sage.

Thompson, L. (1991). Family work: Women's sense of fairness. Journal of Family Issues, 12, $181-196$.

United Nations Development Programme. (2012). Gender inequality index. Last accessed, 4 September 2017: http://hdr.undp.org/en/content/gender-inequality-index-gii

Voicu, M., Voicu, B., and Strapcova, K. (2009). Housework and gender inequality in European countries. European Sociological Review, 25, 365-377.

Walby, S. (2009). Globalization and Inequalities: Complexity and Contested Modernities. London: Sage.

West, C., and Zimmerman, D. H. (1987). Doing gender. Gender and Society, 1, 125-151. 
Table 1. Descriptive statistics of all variables in analysis

\begin{tabular}{|c|c|c|c|c|}
\hline Variable & $\begin{array}{c}\text { Mean/ } \\
\text { Percentage }\end{array}$ & $\begin{array}{l}\text { Std. } \\
\text { dev. }\end{array}$ & Minimum & Maximum \\
\hline \multicolumn{5}{|l|}{ Level 1 ( $N=10,467$ women $)$} \\
\hline Satisfaction with family life (high $=$ satisfied) & 5.64 & 1.02 & 1 & 7 \\
\hline Relational comparison between partners $($ high $=$ fair) & 2.21 & 0.96 & 1 & 5 \\
\hline Referential comparison within country (high $=$ favourable) & -0.03 & 0.43 & -0.99 & 0.99 \\
\hline Share of couple's housework time & 0.71 & 0.19 & 0 & 1 \\
\hline Gender ideology $($ high $=$ egalitarian $)$ & -0.04 & 1.44 & -4.22 & 4.36 \\
\hline Weekly housework time & 19.88 & 14.33 & 0 & 69 \\
\hline Weekly paid work time & 22.36 & 20.61 & 0 & 80 \\
\hline Resource dependence $($ high $=$ dependent $)$ & 4.66 & 1.52 & 1 & 7 \\
\hline Domestic aid & 0.11 & - & 0 & 1 \\
\hline Age & 47.20 & 14.26 & 17 & 79 \\
\hline Unmarried cohabitation $($ ref $=$ married $)$ & 0.14 & - & 0 & 1 \\
\hline Years of schooling & 12.89 & 3.82 & 0 & 20 \\
\hline Self-reported health (high = good) & 3.19 & 1.02 & 1 & 5 \\
\hline \multicolumn{5}{|l|}{ Religious affiliation } \\
\hline No & 0.22 & - & 0 & 1 \\
\hline Catholic & 0.38 & - & 0 & 1 \\
\hline Protestant & 0.22 & - & 0 & 1 \\
\hline Other Christian & 0.10 & - & 0 & 1 \\
\hline Other & 0.08 & - & 0 & 1 \\
\hline \multicolumn{5}{|l|}{ Quartile of household income in country } \\
\hline $1^{\text {st }}$ quartile (lowest) & 0.23 & - & 0 & 1 \\
\hline $2^{\text {nd }}$ quartile & 0.20 & - & 0 & 1 \\
\hline $3^{\text {rd }}$ quartile & 0.19 & - & 0 & 1 \\
\hline $4^{\text {th }}$ quartile (highest) & 0.17 & - & 0 & 1 \\
\hline Missing & 0.20 & - & 0 & 1 \\
\hline \multicolumn{5}{|l|}{ Level $2(N=30$ countries $)$} \\
\hline Level of gender equality (high $=$ equal) & 0.00 & 1.00 & -2.34 & 1.15 \\
\hline Gross domestic product per capita $(\$ 10,000)$ & 3.68 & 2.38 & 0.26 & 10.16 \\
\hline
\end{tabular}

Note: Column percentages may not add up to 1 due to rounding. 
Table 2. Two-level mixed effects regression models predicting women's satisfaction with family life $(N=10,467)$

\begin{tabular}{|c|c|c|c|c|c|}
\hline & M1 & M2 & M3 & M4 & M5 \\
\hline Predictor & $B(S E)$ & $B(S E)$ & $B(S E)$ & $B(S E)$ & $B(S E)$ \\
\hline \multicolumn{6}{|l|}{ Level 1 (individual) } \\
\hline $\begin{array}{l}\text { Relational comparison } \\
\text { between partners }\end{array}$ & & $\begin{array}{l}0.095^{* * *} \\
(0.011)\end{array}$ & & $\begin{array}{l}0.093 * * * \\
(0.011)\end{array}$ & $\begin{array}{l}0.092 * * * \\
(0.011)\end{array}$ \\
\hline $\begin{array}{l}\text { Referential comparison } \\
\text { within country }\end{array}$ & & & $\begin{array}{l}0.302 * * * \\
(0.083)\end{array}$ & $\begin{array}{l}0.261 * * \\
(0.083)\end{array}$ & $\begin{array}{l}0.346 * * * \\
(0.093)\end{array}$ \\
\hline $\begin{array}{l}\text { Relational comparison } \mathrm{x} \\
\text { referential comparison }\end{array}$ & & & & & $\begin{array}{l}-0.044 * \\
(0.022)\end{array}$ \\
\hline $\begin{array}{l}\text { Share of couple's } \\
\text { housework time }\end{array}$ & $\begin{array}{l}-0.577 * * * \\
(0.052)\end{array}$ & $\begin{array}{l}-0.397 * * * \\
(0.056)\end{array}$ & $\begin{array}{l}-0.111 \\
(0.138)\end{array}$ & $\begin{array}{c}0.001 \\
(0.138)\end{array}$ & $\begin{array}{l}-0.020 \\
(0.139)\end{array}$ \\
\hline Weekly housework time & $\begin{array}{l}0.002 * \\
(0.001)\end{array}$ & $\begin{array}{l}0.002 * \\
(0.001)\end{array}$ & $\begin{array}{c}0.001 \\
(0.001)\end{array}$ & $\begin{array}{c}0.002 * \\
(0.001)\end{array}$ & $\begin{array}{c}0.002 * \\
(0.001)\end{array}$ \\
\hline $\begin{array}{l}\text { Gender ideology } \\
\text { (high = egalitarian) }\end{array}$ & $\begin{array}{l}-0.055 * * * \\
(0.007)\end{array}$ & $\begin{array}{l}-0.054 * * * \\
(0.007)\end{array}$ & $\begin{array}{c}0.009 \\
(0.019)\end{array}$ & $\begin{array}{c}0.001 \\
(0.019)\end{array}$ & $\begin{array}{l}-0.001 \\
(0.019)\end{array}$ \\
\hline Weekly paid work time & $\begin{array}{l}-0.002 * * \\
(0.001)\end{array}$ & $\begin{array}{l}-0.002 * * \\
(0.001)\end{array}$ & $\begin{array}{l}-0.002 * * \\
(0.001)\end{array}$ & $\begin{array}{l}-0.002 * * \\
(0.001)\end{array}$ & $\begin{array}{l}-0.002 * * \\
(0.001)\end{array}$ \\
\hline $\begin{array}{l}\text { Resource dependence (high }= \\
\text { dependent) }\end{array}$ & $\begin{array}{l}0.018 * * \\
(0.007)\end{array}$ & $\begin{array}{c}0.016 * \\
(0.007)\end{array}$ & $\begin{array}{l}0.019 * * \\
(0.007)\end{array}$ & $\begin{array}{l}0.017 * \\
(0.007)\end{array}$ & $\begin{array}{c}0.016^{*} \\
(0.007)\end{array}$ \\
\hline \multicolumn{6}{|l|}{ Level 2 (country) } \\
\hline Level of gender equality & $\begin{array}{l}-0.144 * * \\
(0.048)\end{array}$ & $\begin{array}{l}-0.153^{* *} \\
(0.049)\end{array}$ & $\begin{array}{l}-0.132 * * \\
(0.049)\end{array}$ & $\begin{array}{l}-0.143^{* *} \\
(0.051)\end{array}$ & $\begin{array}{l}-0.143^{* *} \\
(0.051)\end{array}$ \\
\hline \multicolumn{6}{|l|}{ Variance components } \\
\hline Variance (country intercept) & $\begin{array}{l}0.042^{* * *} \\
(0.011)\end{array}$ & $\begin{array}{l}0.044^{* * *} \\
(0.012)\end{array}$ & $\begin{array}{l}0.044 * * * \\
(0.012)\end{array}$ & $\begin{array}{l}0.047^{* * *} \\
(0.013)\end{array}$ & $\begin{array}{l}0.047 * * * \\
(0.013)\end{array}$ \\
\hline \multicolumn{6}{|l|}{ Model fit indices } \\
\hline$I C C(\%)($ Null $=7.07)$ & 4.54 & 4.86 & 4.83 & 5.16 & 5.16 \\
\hline$B I C($ Null $=29,567.65)$ & $28,647.05$ & $28,576.48$ & $28,643.11$ & $28,575.92$ & $28,581.15$ \\
\hline$L L($ Null $=-14,769.94)$ & $-14,212.46$ & $-14,172.54$ & $-14,205.86$ & $-14,167.63$ & $-14,165.62$ \\
\hline
\end{tabular}

Note: Models also controlled for respondents' age, age ${ }^{2}$, unmarried cohabitation (as opposed to married), years of schooling, self-reported health, self-reported religious affiliation, level of household income in country, and country gross domestic product per capita in 2012, and individual-level intercept. See Supplementary Table S6 for the results for the covariates. ICC $=$ Intra-class correlation. $\mathrm{BIC}=$ Bayesian information criterion. $\mathrm{LL}=$ Log-likelihood.

$+p<0.10, * p<0.05,{ }^{* *} p<0.01, * * * p<0.001$. 
Table 3. Selected results for cross-level interactions from two-level mixed effects regression models predicting women's satisfaction with family life $(N=10,467)$

\begin{tabular}{|c|c|c|c|c|}
\hline & M6 & M7 & M8 & M9 \\
\hline Predictor & $B(S E)$ & $B(S E)$ & $B(S E)$ & $B(S E)$ \\
\hline \multicolumn{5}{|l|}{ Level 1 (individual) } \\
\hline $\begin{array}{l}\text { Relational comparison between } \\
\text { partners }\end{array}$ & $\begin{array}{l}0.103 * * * \\
(0.016)\end{array}$ & $\begin{array}{l}0.105^{* * *} \\
(0.015)\end{array}$ & $\begin{array}{l}0.093 * * * \\
(0.011)\end{array}$ & $\begin{array}{l}0.093 * * * \\
(0.011)\end{array}$ \\
\hline $\begin{array}{l}\text { Referential comparison within } \\
\text { country }\end{array}$ & $\begin{array}{l}0.266^{* *} \\
(0.084)\end{array}$ & $\begin{array}{l}0.263^{* *} \\
(0.084)\end{array}$ & $\begin{array}{l}0.263 * * \\
(0.087)\end{array}$ & $\begin{array}{l}0.264 * * \\
(0.087)\end{array}$ \\
\hline \multicolumn{5}{|l|}{ Level 2 (country) } \\
\hline Level of gender equality & $\begin{array}{l}-0.197 * * * \\
(0.058)\end{array}$ & $\begin{array}{l}-0.221 * * * \\
(0.058)\end{array}$ & $\begin{array}{l}-0.142^{* *} \\
(0.051)\end{array}$ & $\begin{array}{l}-0.142 * * \\
(0.051)\end{array}$ \\
\hline \multicolumn{5}{|l|}{ Cross-level interactions } \\
\hline $\begin{array}{l}\text { Relational comparison between } \\
\text { partners x country gender equality }\end{array}$ & & $\begin{array}{l}0.030^{*} \\
(0.014)\end{array}$ & & \\
\hline $\begin{array}{l}\text { Referential comparison within } \\
\text { country x country gender equality }\end{array}$ & & & & $\begin{array}{c}0.005 \\
(0.029)\end{array}$ \\
\hline \multicolumn{5}{|l|}{ Variance components } \\
\hline Variance (country intercept) & $\begin{array}{l}0.055^{* *} \\
(0.017)\end{array}$ & $\begin{array}{l}0.051 * * \\
(0.016)\end{array}$ & $\begin{array}{l}0.047 * * * \\
(0.013)\end{array}$ & $\begin{array}{l}0.047 * * * \\
(0.013)\end{array}$ \\
\hline $\begin{array}{l}\text { Variance (relational comparison } \\
\text { between partners) }\end{array}$ & $\begin{array}{c}0.004^{*} \\
(0.002)\end{array}$ & $\begin{array}{c}0.003^{*} \\
(0.001)\end{array}$ & & \\
\hline $\begin{array}{l}\text { Variance (referential comparison } \\
\text { within country) }\end{array}$ & & & $\begin{array}{c}0.012+ \\
(0.007)\end{array}$ & $\begin{array}{c}0.012+ \\
(0.007)\end{array}$ \\
\hline$\%$ reduction in random slopes & & 24.12 & & 0.48 \\
\hline \multicolumn{5}{|l|}{ Model fit indices } \\
\hline $\operatorname{ICC}(\%)$ & 5.95 & 5.58 & 5.15 & 5.15 \\
\hline$B I C$ & $28,564.21$ & $28,569.16$ & $28,579.52$ & $28,588.74$ \\
\hline$L L$ & $-14,157.15$ & $-14,155.00$ & $-14,164.80$ & $-14,164.79$ \\
\hline
\end{tabular}

Note: Models also controlled for all variables reported in Table 2, respondents' age, age ${ }^{2}$, unmarried cohabitation (as opposed to married), years of schooling, self-reported health, self-reported religious affiliation, level of household income in country, country gross domestic product per capita in 2012, and individual-level intercept. See Supplementary Table S6 for the results for the covariates. ICC = Intra-class correlation. BIC = Bayesian information criterion. $\mathrm{LL}=\mathrm{Log}$-likelihood.

$+p<0.10,{ }^{*} p<0.05,{ }^{* *} p<0.01,{ }^{* * *} p<0.001$. 


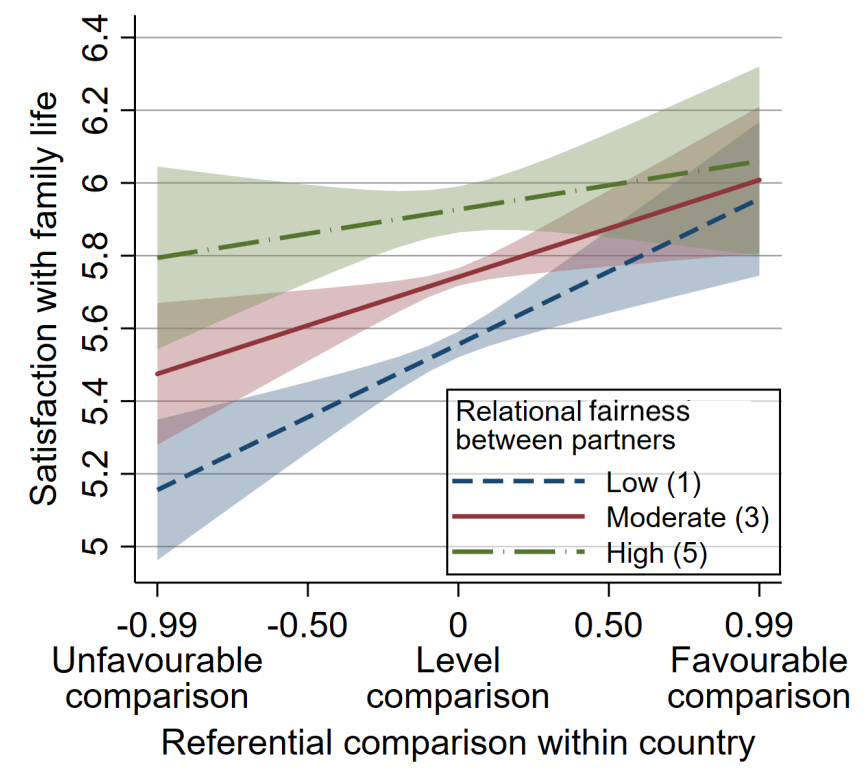

Figure 1. Predictive margin of women's satisfaction with family life by referential comparison within country, at distinct levels of relational fairness.

Note: Prediction based on Model 5 in Table 2. Colour bands indicate 95\% confidence intervals. Unfavourable comparison means one falls on the more traditional end of the relative rank of housework share than one's position on the rank of gender ideology vis-à-vis other women in the same country. Favourable comparison means one falls on the less traditional end of the rank of housework share than one's position on the rank of gender ideology vis-à-vis other women in the same country. Level comparison means one's relative ranks vis-à-vis other women in the same country in terms of housework share and gender ideology are similar. 


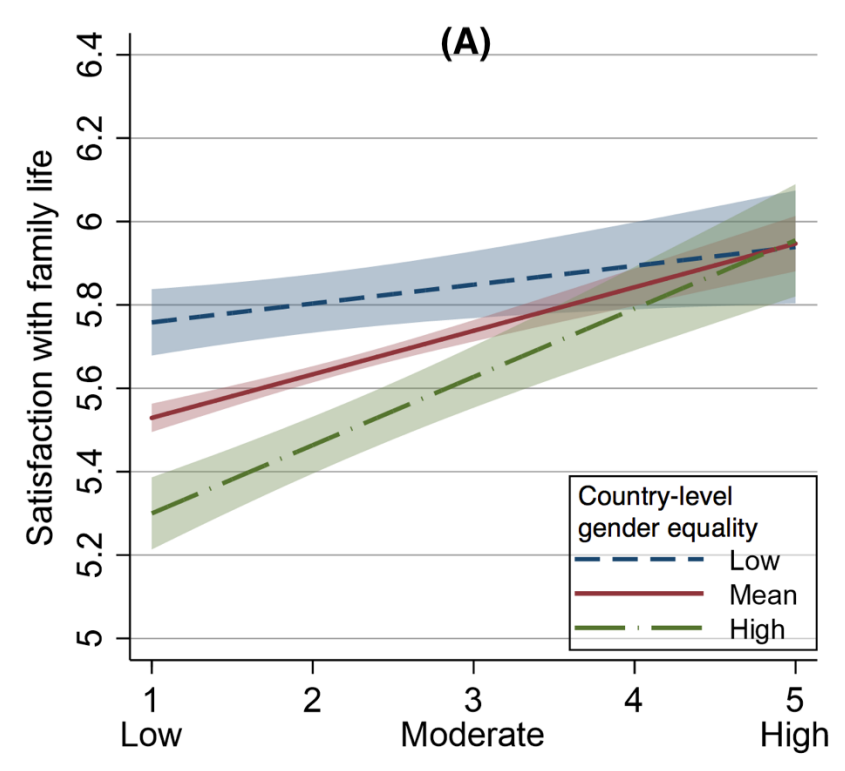

Relational fairness between partners

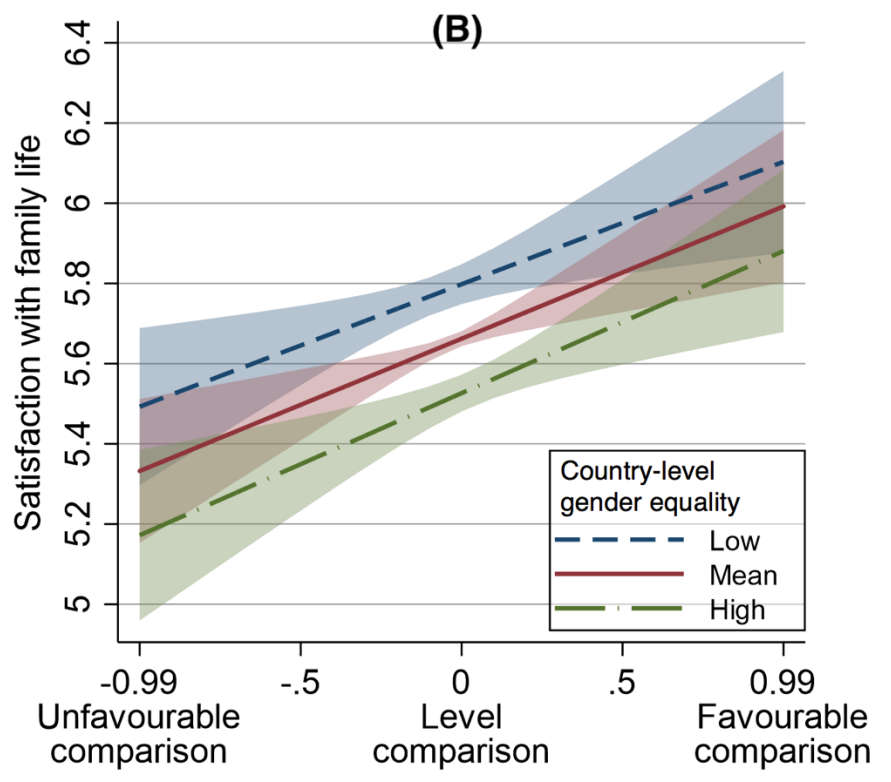

Referential comparison within country

Figure 2. Predictive margin of women's satisfaction with family life by relational fairness between partners and referential comparison within country, by level of gender equality in country.

Note: Predictions based on Model 7 and Model 9 in Table 3. Colour bands indicate 95\% confidence intervals. Low and high levels refer to 1 standard deviation below and above the grand mean value, respectively. Unfavourable comparison means one falls on the more traditional end of the relative rank of housework share than one's position on the rank of gender ideology vis-à-vis other women in the same country. Favourable comparison means one falls on the less traditional end of the rank of housework share than one's position on the rank of gender ideology vis-à-vis other women in the same country. Level comparison means one's relative ranks vis-à-vis other women in the same country in terms of housework share and gender ideology are similar. 


\section{Online Supplement}

\section{What fairness? Gendered division of housework and family life satisfaction across 30 countries}

\section{Descriptive statistics for key variables aggregated at country level (Table S1).}

2. Validity and reliability of time-use measures (Table S2). We verified the validity and reliability of the time-use measures (e.g. women's share of couples' housework time) in the 2012 ISSP by comparing our data with those reported in previous research (Greenstein, 2009; Knudsen \& Wærness, 2008). The results confirmed the reliability and validity of the measures used in this research.

3. Alternative coding and sample for relational comparison between partners (Table S3 Panel A and S4 Panel A). As detailed in the article, we conducted robustness tests using the ordinal coding of relational comparison between partners based on the sample excluding women who reported doing less than their fair share of housework compared with their partners (Braun et al., 2008). The results of the additional models were highly consistent with those reported in the article.

4. Sample age range (Table S3 Panel B and Table S4 Panel B). Following a number of existing studies (e.g. Braun et al., 2008; Forste and Fox, 2012; Greenstein, 2009), our analytical sample covered a wide age range: from 17 to 79 years old. To account for any potential heterogeneity arising from this wide age span, we controlled for respondents' age as both a linear and a quadratic regressor in all of our models. To further ensure the robustness of the results, we conducted additional checks based on the analytical sample excluding the top $15 \%$ and bottom $15 \%$ of respondents in the percentile ranking for age. The results based on this restricted sample of respondents (aged between 30 and 60) were consistent with those reported in the article.

5. Non-linearity of age and weekly paid work time (Table S3 Panel C and Table S4 Panel C). Although we included the quadratic term of age in all our models, it is possible that the women who were born between the 1940s and early 1960s may be particularly influenced by the hegemonic female-housekeeping norm. In contrast, the younger women were socialised in an environment that might have considerably redefined women's gender role. We tested this non-linear cohort shift by including a dummy variable indicating whether the women were born before 1965, in addition to the linear and quadratic terms of age. Similarly, it is possible that the relationship between the time women spend on paid work and their gender role self-assessment/share of housework may not be linear. To ensure that our results are robust to any non-linearity in the influence of paid work time, we tested all models by including a dummy variable distinguishing between full-time employment (weekly paid work time $>35$ hours) and no/part-time employment, in addition to the continuous measure of women's weekly paid work time. The results reported in the article are robust to the inclusion of the two dummy variables in all models.

6. Individual-level interactions (Table S5). Existing research has indicated that the relationship between housework division and family life satisfaction may be moderated by individual-level factors such as gender ideology, relative resources and time availability/constraints (Braun et al., 2008; Greenstein, 2009; Major, 1993). Although our 
main aim was not to examine these individual-level moderating effects, the inclusion of these interaction terms may have influenced the interpretation of the results for our key variables and the cross-level interactions on which we focused in this research. Therefore, we also fitted additional models including a number of individual-level interactions. The results reported in the article are robust to the inclusion of the individual-level interactions.

7. Results for control variables (Table S6). To conserve space, we omitted the results for the covariates from the tables included in the article. As the results for the covariates were highly consistent across the models, we present the results for the covariates from the full models based on the full sample and the restricted sample (aged between 30 and 60) (i.e. Model 4 in Table 2 and Table S4 Panel B) in the supplementary tables. 
Table S1. Descriptive statistics of key variables by country

\begin{tabular}{|c|c|c|c|c|c|c|c|c|}
\hline \multirow[b]{2}{*}{ Country } & \multicolumn{2}{|c|}{$\begin{array}{r}\text { Women's Relational } \\
\text { Satisfactioncompariso } \\
\text { with } n \text { between }\end{array}$} & \multirow{2}{*}{$\begin{array}{c}\text { Referential } \\
\text { comparison } \\
\text { within h } \\
\text { country } \\
\end{array}$} & \multirow{2}{*}{\multicolumn{2}{|c|}{$\begin{array}{l}\text { Women's } \\
\text { share of } \\
\text { couple's Weekly } \\
\text { lousework housework }\end{array}$}} & \multirow{2}{*}{$\begin{array}{r}\text { Gender } \\
\text { ideology }\end{array}$} & \multirow{2}{*}{$\begin{array}{r}\text { Country- } \\
\text { level } \\
\text { gender } \\
\text { equality }\end{array}$} & \multirow{2}{*}{$\begin{array}{r}\text { GDP per } \\
\text { capita } \\
(\$ 10,000)\end{array}$} \\
\hline & family life & partners & & & & & & \\
\hline Argentina & 6.07 & 2.08 & -0.04 & 0.75 & 31.69 & 0.86 & -2.12 & 1.44 \\
\hline Australia & 5.75 & 1.96 & -0.02 & 0.64 & 17.28 & -0.22 & 0.32 & 6.75 \\
\hline Austria & 5.75 & 1.99 & -0.02 & 0.74 & 20.00 & 0.78 & 0.83 & 4.83 \\
\hline Bulgaria & 5.63 & 2.23 & -0.04 & 0.74 & 22.25 & 0.34 & -0.54 & 0.72 \\
\hline Canada & 5.73 & 1.98 & -0.03 & 0.67 & 15.48 & -0.58 & 0.11 & 5.27 \\
\hline Chile & 5.74 & 2.11 & -0.04 & 0.81 & 35.15 & 0.85 & -1.88 & 1.53 \\
\hline Croatia & 5.93 & 2.16 & -0.01 & 0.76 & 25.54 & 0.11 & -0.22 & 1.32 \\
\hline Czech & 5.44 & 2.14 & -0.02 & 0.71 & 21.24 & -0.41 & 0.55 & 1.97 \\
\hline Denmark & 5.79 & 2.55 & -0.03 & 0.64 & 11.65 & -0.81 & 0.83 & 5.76 \\
\hline Finland & 5.61 & 2.34 & -0.02 & 0.68 & 12.27 & -0.83 & 0.66 & 4.74 \\
\hline France & 5.56 & 2.14 & -0.03 & 0.73 & 11.84 & -0.17 & 0.62 & 4.09 \\
\hline Germany & 5.62 & 2.18 & -0.02 & 0.72 & 17.13 & -0.25 & 0.93 & 4.39 \\
\hline Iceland & 5.98 & 2.37 & -0.02 & 0.65 & 13.22 & -0.86 & 0.54 & 4.44 \\
\hline Ireland & 5.68 & 1.93 & -0.02 & 0.73 & 18.32 & -0.34 & 0.30 & 4.84 \\
\hline Israel & 5.83 & 2.34 & -0.04 & 0.75 & 19.13 & 0.45 & 0.43 & 3.25 \\
\hline Japan & 5.06 & 1.84 & -0.03 & 0.86 & 24.27 & -0.80 & 0.09 & 4.67 \\
\hline Korea (South) & 4.96 & 2.84 & -0.04 & 0.78 & 21.90 & 0.86 & 0.43 & 2.45 \\
\hline Latvia & 5.35 & 2.30 & -0.02 & 0.67 & 22.66 & 0.46 & -0.67 & 1.40 \\
\hline Lithuania & 4.91 & 2.29 & -0.02 & 0.69 & 25.23 & 0.45 & 0.29 & 1.43 \\
\hline Mexico & 5.81 & 2.13 & -0.06 & 0.77 & 28.49 & 0.89 & -2.07 & 0.97 \\
\hline Norway & 5.64 & 2.32 & -0.02 & 0.70 & 12.00 & -0.41 & 0.73 & 10.16 \\
\hline Philippines & 5.89 & 1.82 & -0.02 & 0.68 & 25.45 & 0.30 & -2.34 & 0.26 \\
\hline Poland & 5.89 & 2.16 & -0.02 & 0.67 & 24.44 & 0.05 & 0.08 & 1.30 \\
\hline Russia & 5.45 & 2.38 & -0.03 & 0.68 & 26.01 & 0.49 & -1.51 & 1.41 \\
\hline Slovakia & 5.60 & 2.42 & -0.02 & 0.69 & 22.92 & -0.52 & -0.15 & 1.72 \\
\hline Slovenia & 5.56 & 2.39 & -0.03 & 0.75 & 26.02 & -0.14 & 1.15 & 2.25 \\
\hline Sweden & 5.56 & 2.37 & -0.03 & 0.64 & 13.75 & -0.89 & 0.85 & 5.71 \\
\hline Switzerland & 5.93 & 2.24 & -0.02 & 0.75 & 19.42 & 0.25 & 1.07 & 8.33 \\
\hline UK & 5.89 & 2.15 & -0.02 & 0.67 & 13.43 & -0.32 & -0.41 & 4.11 \\
\hline USA & 5.88 & 2.13 & -0.03 & 0.66 & 13.41 & -0.19 & -1.04 & 5.15 \\
\hline
\end{tabular}


European Sociological Review Author Accepted Manuscript: Hu \& Yucel

Table S2. Verification of measure reliability and validity (women's share of housework) against external data sources

\begin{tabular}{|c|c|c|c|}
\hline Country & $\begin{array}{l}\text { ISSP } 2012 \text { used in } \\
\text { this research }\end{array}$ & $\begin{array}{c}\text { Knudsen \& } \\
\text { Warness (2008) } \\
\text { European } \\
\text { Sociological Review } \\
\text { (ISSP 2002) } \\
\end{array}$ & $\begin{array}{c}\text { Greenstein (2009) } \\
\text { Journal of Marriage } \\
\text { and Family (ISSP } \\
\text { 2002) }\end{array}$ \\
\hline Argentina & 0.75 & - & - \\
\hline Australia & 0.64 & 0.67 & 0.69 \\
\hline Austria & 0.74 & 0.77 & 0.78 \\
\hline Bulgaria & 0.74 & 0.69 & 0.71 \\
\hline Canada & 0.67 & - & - \\
\hline Chile & 0.81 & 0.80 & 0.81 \\
\hline Croatia & 0.76 & - & - \\
\hline Czech & 0.71 & 0.71 & 0.73 \\
\hline Denmark & 0.64 & 0.66 & 0.69 \\
\hline Finland & 0.68 & 0.67 & 0.69 \\
\hline France & 0.73 & 0.77 & 0.81 \\
\hline Germany & 0.72 & 0.76 & 0.75 \\
\hline Iceland & 0.65 & - & - \\
\hline Ireland & 0.73 & 0.76 & 0.79 \\
\hline Israel & 0.75 & 0.74 & 0.75 \\
\hline Japan & 0.86 & 0.91 & 0.89 \\
\hline South Korea & 0.78 & - & - \\
\hline Latvia & 0.67 & 0.64 & 0.66 \\
\hline Lithuania & 0.69 & - & - \\
\hline Mexico & 0.77 & 0.69 & 0.71 \\
\hline Norway & 0.70 & 0.73 & 0.76 \\
\hline Philippines & 0.68 & 0.64 & - \\
\hline Poland & 0.67 & 0.64 & 0.65 \\
\hline Russia & 0.68 & 0.67 & 0.68 \\
\hline Slovakia & 0.69 & 0.68 & 0.69 \\
\hline Slovenia & 0.75 & 0.73 & - \\
\hline Sweden & 0.64 & 0.66 & 0.68 \\
\hline Switzerland & 0.75 & 0.77 & 0.78 \\
\hline United Kingdom & 0.67 & 0.71 & 0.73 \\
\hline United States & 0.66 & 0.67 & 0.71 \\
\hline
\end{tabular}


Table S3. Two-level mixed effects regression models predicting women's satisfaction with family life (alternative to Table 2 in the article)

\begin{tabular}{|c|c|c|c|c|c|}
\hline Predictor & $B(S E)$ & $B(S E)$ & $B(S E)$ & $B(S E)$ & $B(S E)$ \\
\hline \multicolumn{6}{|l|}{$\begin{array}{l}\text { PANEL A: Sample excluding re } \\
\text { (very unfair [1], unfair [2] and } \\
\text { Level } 1 \text { (individual) } \\
\text { Relational comparison between } \\
\text { partners (ref = very unfair) }\end{array}$} \\
\hline Unfair & & $\begin{array}{l}0.150 * * * \\
(0.025)\end{array}$ & & $\begin{array}{l}0.147 * * * \\
(0.025)\end{array}$ & $\begin{array}{l}0.127 * * * \\
(0.026)\end{array}$ \\
\hline Fair & & $\begin{array}{l}0.275 * * * \\
(0.024)\end{array}$ & & $\begin{array}{l}0.270 * * * \\
(0.025)\end{array}$ & $\begin{array}{l}0.255^{* * *} \\
(0.025)\end{array}$ \\
\hline $\begin{array}{l}\text { Referential comparison within } \\
\text { country }\end{array}$ & & & $\begin{array}{l}0.264 * * \\
(0.089)\end{array}$ & $\begin{array}{c}0.164+ \\
(0.089)\end{array}$ & $\begin{array}{l}0.259 * * \\
(0.096)\end{array}$ \\
\hline $\begin{array}{l}\text { Relational comparison (very } \\
\text { unfair) x referential comparison }\end{array}$ & & & & & \\
\hline Unfair $\mathrm{x}$ referential comparison & & & & & $\begin{array}{c}-0.096+ \\
(0.054)\end{array}$ \\
\hline Fair $\mathrm{x}$ referential comparison & & & & & $\begin{array}{l}-0.173 * * \\
(0.060)\end{array}$ \\
\hline Share of couple's housework time & $\begin{array}{l}-0.612 * * * \\
(0.055)\end{array}$ & $\begin{array}{l}-0.402 * * * \\
(0.058)\end{array}$ & $\begin{array}{l}-0.193 \\
(0.152)\end{array}$ & $\begin{array}{l}-0.144 \\
(0.151)\end{array}$ & $\begin{array}{l}-0.126 \\
(0.151)\end{array}$ \\
\hline Weekly housework time & $\begin{array}{c}0.001 \\
(0.001)\end{array}$ & $\begin{array}{c}0.001+ \\
(0.001)\end{array}$ & $\begin{array}{c}0.001 \\
(0.001)\end{array}$ & $\begin{array}{c}0.001 \\
(0.001)\end{array}$ & $\begin{array}{c}0.001 \\
(0.001)\end{array}$ \\
\hline $\begin{array}{l}\text { Gender ideology }(\text { high }= \\
\text { egalitarian) }\end{array}$ & $\begin{array}{l}-0.051 * * * \\
(0.007)\end{array}$ & $\begin{array}{l}-0.050 * * * \\
(0.007)\end{array}$ & $\begin{array}{c}0.004 \\
(0.020)\end{array}$ & $\begin{array}{l}-0.015 \\
(0.020)\end{array}$ & $\begin{array}{c}-0.014 \\
(0.020)\end{array}$ \\
\hline Weekly paid work time & $\begin{array}{l}-0.002 * * \\
(0.001)\end{array}$ & $\begin{array}{r}-0.001^{*} \\
(0.001)\end{array}$ & $\begin{array}{l}-0.002 * * \\
(0.001)\end{array}$ & $\begin{array}{r}-0.001^{*} \\
(0.001)\end{array}$ & $\begin{array}{r}-0.001^{*} \\
(0.001)\end{array}$ \\
\hline $\begin{array}{l}\text { Resource dependence (high }= \\
\text { dependent) }\end{array}$ & $\begin{array}{l}0.019 * * \\
(0.007)\end{array}$ & $\begin{array}{c}0.016^{*} \\
(0.007)\end{array}$ & $\begin{array}{l}0.020 * * \\
(0.007)\end{array}$ & $\begin{array}{c}0.016^{*} \\
(0.007)\end{array}$ & $\begin{array}{c}0.016^{*} \\
(0.007)\end{array}$ \\
\hline Level 2 (country) & & & & & \\
\hline Level of gender equality & $\begin{array}{c}-0.138 * * \\
(0.047)\end{array}$ & $\begin{array}{c}-0.153^{* *} \\
(0.048)\end{array}$ & $\begin{array}{c}-0.127 * * \\
(0.048)\end{array}$ & $\begin{array}{c}-0.147 * * \\
(0.048)\end{array}$ & $\begin{array}{c}-0.146 * * \\
(0.048)\end{array}$ \\
\hline
\end{tabular}

PANEL B: Sample aged between 30 and 60

Level 1 (individual)

Relational comparison between partners

Referential comparison within country

(0.012)

Relational comparison $\mathrm{x}$

referential comparison

Share of couple's housework time

Weekly housework time

Gender ideology $($ high $=$ egalitarian)

Weekly paid work time

Resource dependence (high $=$ dependent)

Level 2 (country)

Level of gender equality
$0.103 * * *$

\begin{tabular}{|c|c|c|c|c|}
\hline & $0.103 * * *$ & & $0.102 * * *$ & $0.101 * * *$ \\
\hline & $(0.012)$ & & $(0.012)$ & $(0.012)$ \\
\hline & & $0.245^{*}$ & $0.199 *$ & $0.307 * *$ \\
\hline & & $(0.095)$ & $(0.095)$ & $(0.107)$ \\
\hline & & & & $-0.056^{*}$ \\
\hline & & & & $(0.025)$ \\
\hline$-0.595 * * *$ & $-0.397 * * *$ & -0.217 & -0.093 & -0.117 \\
\hline$(0.060)$ & $(0.064)$ & $(0.159)$ & $(0.159)$ & $(0.160)$ \\
\hline $0.002+$ & $0.002 *$ & 0.001 & $0.002+$ & $0.002 *$ \\
\hline$(0.001)$ & $(0.001)$ & $(0.001)$ & $(0.001)$ & $(0.001)$ \\
\hline$-0.062 * * *$ & $-0.061 * * *$ & -0.011 & -0.019 & -0.022 \\
\hline$(0.008)$ & $(0.008)$ & $(0.022)$ & $(0.022)$ & $(0.022)$ \\
\hline$-0.002 *$ & $-0.001 *$ & $-0.002 *$ & $-0.001 *$ & $-0.001 *$ \\
\hline$(0.001)$ & $(0.001)$ & $(0.001)$ & $(0.001)$ & $(0.001)$ \\
\hline $0.025 * *$ & $0.023 * *$ & $0.025^{* *}$ & $0.023 * *$ & $0.023 * *$ \\
\hline$(0.008)$ & $(0.008)$ & $(0.008)$ & $(0.008)$ & $(0.008)$ \\
\hline$-0.160 * *$ & $-0.170 * * *$ & $-0.151 * *$ & $-0.163^{* *}$ & $-0.164 * *$ \\
\hline$(0.050)$ & $(0.051)$ & $(0.051)$ & $(0.052)$ & $(0.052)$ \\
\hline
\end{tabular}

PANEL C: Including dummy variables for women born before 1965 (in addition to age and age ${ }^{2}$ ) and fulltime employment (in addition to weekly work hours)

Level 1 (individual)

Relational comparison between

$0.095 * * *$

$0.093 * * * \quad 0.092 * * *$ 
European Sociological Review Author Accepted Manuscript: Hu \& Yucel

partners

Referential comparison within country

Relational comparison $\mathrm{x}$ referential comparison

Share of couple's housework time

Weekly housework time

Gender ideology $($ high $=$ egalitarian)

Weekly paid work time

Resource dependence (high $=$ dependent)

Born before 1965 (ref = no)

Full-time employment $($ ref $=$ no $)$

Level 2 (country)

Level of gender equality
$(0.011)$

$0.305 * * *$
$(0.083)$

$(0.011)$

$(0.011)$

$-0.401 * * *$

$(0.056)$

$0.002 *$

$(0.001)$

$(0.001)$

$-0.055^{* * *}$

$-0.055^{* * *}$

$(0.007)$

0.007

$-0.001$

$-0.000$

$(0.018 * *$

$(0.001)$

$0.016^{*}$

(0.007)

0.037

$(0.034)$

$(0.034)$

$-0.050$

(0.038)

$-0.053$

(0.038)

$-0.152 * *$

$(0.049)$

Note: Control variables included for all models.

$+p<0.10,{ }^{*} p<0.05,{ }^{* *} p<0.01, * * * p<0.001$
$(0.083)$

$-0.111$

(0.138)

$0.001+$

(0.001)

0.009

(0.019)

$-0.001$

(0.001)

$0.019 * *$

(0.007)

0.042

(0.034)

$-0.052$

(0.038)

$\begin{array}{ll}0.264 * * & 0.348 * * * \\ (0.083) & (0.093)\end{array}$

$-0.043 *$

(0.022)

$0.001 \quad-0.020$

$(0.138) \quad(0.139)$

$0.002 * \quad 0.002 *$

$(0.001) \quad(0.001)$

$0.001 \quad-0.001$

$(0.019) \quad(0.019)$

$-0.000 \quad-0.000$

$(0.001) \quad(0.001)$

0.016* $0.016^{*}$

$(0.007) \quad(0.007)$

$0.038 \quad 0.038$

$(0.034) \quad(0.034)$

$-0.055 \quad-0.054$

$(0.038) \quad(0.038)$

$-0.131 * *$

$-0.141 * *$

$-0.142 * *$

(0.049)

(0.051)

$(0.051)$ 
Table S4. Selected results for cross-level interactions from two-level mixed effects regression models predicting women's satisfaction with family life (alternative to Table 3 in the article)

\begin{tabular}{|c|c|c|}
\hline Predictor & $B(S E)$ & $B(S E)$ \\
\hline \multirow{2}{*}{\multicolumn{3}{|c|}{$\begin{array}{l}\text { PANEL A: Sample excluding relational comparison }[4,5] \text { and ordinal coding for relational comparison } \\
\text { (very unfair [1], unfair }[2] \text { and fair }[3] \text { ) } \\
\text { Level } 1 \text { (individual) }\end{array}$}} \\
\hline & & \\
\hline \multicolumn{3}{|c|}{$\begin{array}{l}\text { Relational comparison between partners (ref }=\text { very } \\
\text { unfair) }\end{array}$} \\
\hline Unfair & $\begin{array}{c}0.152 * * * \\
(0.025)\end{array}$ & $\begin{array}{l}- \\
-\end{array}$ \\
\hline Fair & $\begin{array}{c}0.284 * * * \\
(0.033)\end{array}$ & - \\
\hline \multicolumn{3}{|l|}{ Level 2 (country) } \\
\hline Level of gender equality & $\begin{array}{l}-0.212 * * * \\
\quad(0.051)\end{array}$ & - \\
\hline \multicolumn{3}{|l|}{ Cross-level interactions } \\
\hline \multicolumn{3}{|c|}{$\begin{array}{l}\text { Relational comparison (ref = very unfair) } \mathrm{x} \text { country } \\
\text { gender equality }\end{array}$} \\
\hline Unfair $\mathrm{x}$ country gender equality & $\begin{array}{c}0.074 * * \\
(0.025)\end{array}$ & $\begin{array}{l}- \\
-\end{array}$ \\
\hline Fair $x$ country gender equality & $\begin{array}{l}0.102 * * \\
(0.032)\end{array}$ & - \\
\hline
\end{tabular}

PANEL B: Sample aged between 30 and 60

Level 1 (individual)

Relational comparison between partners

$\begin{array}{cc}0.112 * * * & 0.102 * * * \\ (0.016) & (0.012) \\ 0.203 * & 0.203 * \\ (0.096) & (0.098) \\ & \\ -0.237 * * * & -0.161 * * \\ (0.058) & (0.052) \\ & \\ 0.030 * & \\ (0.015) & \end{array}$

Referential comparison within country

Level 2 (country)

Level of gender equality

\section{Cross-level interactions}

Relational comparison $\mathrm{x}$ country gender equality

Referential comparison x country gender equality

PANEL C: Including dummy variables for women born before 1965 (in addition to age and age ${ }^{2}$ ) and full-time employment (in addition to weekly work hours)

Level 1 (individual)

Relational comparison between partners

$\begin{array}{cc}0.075 * * * & 0.093 * * * \\ (0.020) & (0.011) \\ 0.265 * * & 0.260 * * \\ (0.084) & (0.091) \\ & \\ -0.219 * * * & -0.140 * * \\ (0.057) & (0.050) \\ & \\ 0.030 * & \\ (0.014) & \end{array}$

Referential comparison $\mathrm{x}$ country gender equality

Note: Control variables included for all models.

$+p<0.10, * p<0.05, * * p<0.01, * * * p<0.001$ 
Table S5. Selected results for cross-level interactions from two-level mixed effects regression models predicting women's satisfaction with family life (full sample including individual-level interactions, alternative to Table 3 in the article)

\begin{tabular}{|c|c|c|}
\hline Predictor & $B(S E)$ & $B(S E)$ \\
\hline \multicolumn{3}{|l|}{ Level 1 (individual) } \\
\hline Relational comparison between partners & $\begin{array}{l}0.162 * * * * \\
(0.038)\end{array}$ & $\begin{array}{l}0.162 * * * \\
(0.037)\end{array}$ \\
\hline Referential comparison within country & $\begin{array}{c}0.221+ \\
(0.118)\end{array}$ & $\begin{array}{c}0.210+ \\
(0.121)\end{array}$ \\
\hline Share of couple's housework time & $\begin{array}{c}0.036 \\
(0.141)\end{array}$ & $\begin{array}{c}0.017 \\
(0.141)\end{array}$ \\
\hline Weekly housework time & $\begin{array}{c}0.002 * \\
(0.001)\end{array}$ & $\begin{array}{c}0.002 * \\
(0.001)\end{array}$ \\
\hline Gender ideology $($ high $=$ egalitarian $)$ & $\begin{array}{c}0.015 \\
(0.024)\end{array}$ & $\begin{array}{c}0.031 \\
(0.024)\end{array}$ \\
\hline Weekly paid work time & $\begin{array}{c}-0.000 \\
(0.001)\end{array}$ & $\begin{array}{c}-0.000 \\
(0.001)\end{array}$ \\
\hline Resource dependence (high $=$ dependent $)$ & $\begin{array}{r}0.037^{*} \\
(0.016)\end{array}$ & $\begin{array}{l}0.041^{* *} \\
(0.016)\end{array}$ \\
\hline \multicolumn{3}{|l|}{ Individual-level interactions } \\
\hline Relational comparison $\mathrm{x}$ gender ideology & $\begin{array}{l}-0.006 \\
(0.007)\end{array}$ & $\begin{array}{c}-0.013+ \\
(0.007)\end{array}$ \\
\hline Relational comparison $\mathrm{x}$ weekly paid work time & $\begin{array}{l}-0.001 \\
(0.000)\end{array}$ & $\begin{array}{l}-0.001 \\
(0.000)\end{array}$ \\
\hline Relational comparison $\mathrm{x}$ resource dependence & $\begin{array}{l}-0.010 \\
(0.007)\end{array}$ & $\begin{array}{c}-0.011+ \\
(0.007)\end{array}$ \\
\hline Referential comparison $\mathrm{x}$ gender ideology & $\begin{array}{c}0.000 \\
(0.016)\end{array}$ & $\begin{array}{c}0.002 \\
(0.017)\end{array}$ \\
\hline Referential comparison $\mathrm{x}$ weekly paid work time & $\begin{array}{c}0.001 \\
(0.001)\end{array}$ & $\begin{array}{c}0.001 \\
(0.001)\end{array}$ \\
\hline Referential comparison $\mathrm{x}$ resource dependence & $\begin{array}{c}0.007 \\
(0.015)\end{array}$ & $\begin{array}{c}0.009 \\
(0.015)\end{array}$ \\
\hline \multicolumn{3}{|l|}{ Level 2 (country) } \\
\hline Level of gender equality & $\begin{array}{l}-0.216^{* * *} \\
(0.058)\end{array}$ & $\begin{array}{c}-0.141 * * \\
(0.050)\end{array}$ \\
\hline \multicolumn{3}{|l|}{ Cross-level interactions } \\
\hline Relational comparison $\mathrm{x}$ country gender equality & $\begin{array}{c}0.028^{*} \\
(0.014)\end{array}$ & \\
\hline Referential comparison $\mathrm{x}$ country gender equality & & $\begin{array}{c}0.002 \\
(0.029)\end{array}$ \\
\hline
\end{tabular}

Note: Control variables included for all models.

$+p<0.10,{ }^{*} p<0.05, * * p<0.01,{ }^{* * *} p<0.001$ 
Table S6. Results for control variables from two-level mixed effects regression models predicting women's satisfaction with family life (continues from Model 4 in Table 2 in the article and Table S3 Panel B)

\begin{tabular}{|c|c|c|}
\hline & Full sample & $\begin{array}{c}\text { Sample aged } 30 \text { to } \\
60\end{array}$ \\
\hline Predictor & $B(S E)$ & $B(S E)$ \\
\hline \multicolumn{3}{|l|}{ Level 1 (individual) } \\
\hline Individual-level intercept & $\begin{array}{l}4.849 * * * \\
(0.181)\end{array}$ & $\begin{array}{l}5.069 * * * \\
(0.309)\end{array}$ \\
\hline Domestic aid $(\mathrm{ref}=$ no $)$ & $\begin{array}{c}-0.055+ \\
(0.030)\end{array}$ & $\begin{array}{l}-0.009 \\
(0.036)\end{array}$ \\
\hline Unmarried cohabitation ( ref $=$ married $)$ & $\begin{array}{l}-0.196^{* * * *} \\
(0.030)\end{array}$ & $\begin{array}{l}-0.194 * * * \\
(0.036)\end{array}$ \\
\hline Age/10 & $\begin{array}{l}-0.235^{* * * *} \\
(0.044)\end{array}$ & $\begin{array}{l}-0.328 * * \\
(0.116)\end{array}$ \\
\hline $\mathrm{Age}^{2} / 100$ & $\begin{array}{l}0.021^{* * * *} \\
(0.005)\end{array}$ & $\begin{array}{r}0.032 * \\
(0.012)\end{array}$ \\
\hline Years of schooling & $(0.001$ & $\begin{array}{l}-0.001 \\
(0.003)\end{array}$ \\
\hline Self-reported health (high = good) & $\begin{array}{l}0.258 * * * \\
(0.010)\end{array}$ & $\begin{array}{l}0.258 * * * \\
(0.012)\end{array}$ \\
\hline \multicolumn{3}{|l|}{ Self-reported religious affiliation $(\mathrm{ref}=\mathrm{no})$} \\
\hline Catholic & $\begin{array}{c}0.065^{*} \\
(0.029)\end{array}$ & $\begin{array}{c}0.061+ \\
(0.033)\end{array}$ \\
\hline Protestant & $\begin{array}{c}0.047 \\
(0.034)\end{array}$ & $\begin{array}{c}0.060 \\
(0.039)\end{array}$ \\
\hline Other Christian & $\begin{array}{c}0.066 \\
(0.043)\end{array}$ & $\begin{array}{c}0.037 \\
(0.049)\end{array}$ \\
\hline Other & $\begin{array}{c}0.072 \\
(0.047)\end{array}$ & $\begin{array}{c}0.052 \\
(0.054)\end{array}$ \\
\hline \multicolumn{3}{|c|}{$\begin{array}{l}\text { Level of household income in country (ref }=1 \text { st quartile } \\
\text { [lowest]) }\end{array}$} \\
\hline 2nd quartile & $\begin{array}{l}0.118 * * * \\
(0.028)\end{array}$ & $\begin{array}{l}0.125^{* * * *} \\
(0.034)\end{array}$ \\
\hline 3rd quartile & $\begin{array}{l}0.112 * * * \\
(0.030)\end{array}$ & $\begin{array}{l}0.113 * * \\
(0.035)\end{array}$ \\
\hline 4th quartile (highest) & $\begin{array}{l}0.130^{* * * *} \\
(0.032)\end{array}$ & $\begin{array}{l}0.131^{* * * *} \\
(0.037)\end{array}$ \\
\hline Missing & $\begin{array}{l}0.126^{* * * *} \\
(0.030)\end{array}$ & $\begin{array}{l}0.147 * * * \\
(0.035)\end{array}$ \\
\hline $\begin{array}{l}\text { Level } 2 \text { (country) } \\
\text { Gross domestic product per capita }(\$ 10,000)\end{array}$ & $\begin{array}{l}0.044 * \\
(0.022)\end{array}$ & $\begin{array}{c}0.050^{*} \\
(0.022)\end{array}$ \\
\hline
\end{tabular}

Note: Control variables included for all models.

$+p<0.10,{ }^{*} p<0.05,{ }^{* *} p<0.01,{ }^{* * *} p<0.001$ 
European Sociological Review Author Accepted Manuscript: Hu \& Yucel

\section{References}

Braun, M., Lewin-Epstein, N., Stier, H., and Baumgärtner, M. K. (2008). Perceived equity in the gendered division of household labor. Journal of Marriage and Family, 70, 11451156.

Bryan, M. L., and Jenkins, S. P. (2016). Multilevel modelling of country effects: A cautionary tale. European Sociological Review, 32, 3-22.

Forste, R., and Fox, K. (2012). Household labor, gender roles, and family satisfaction: A cross-national comparison. Journal of Comparative Family Studies, 43, 613-631.

Greenstein, T. N. (2009). National context, family satisfaction, and fairness in the division of household labor. Journal of Marriage and Family, 71, 1039-1051.

Knudsen, K., and Wærness, K. (2008). National context and spouses' housework in 34 countries. European Sociological Review, 24, 97-113.

Major, B. (1993). Gender, entitlement, and the distribution of family labor. Journal of Social Issues, 49, 141-159. 